\title{
Rytuały jedzenia i picia we Francji i w Polsce. Rekonesans
}

Michał Masłowski 
nAPPS Seria X 2004

\section{Michał Masłowski}

\section{Rytuały jedzenia i picia we Francji i w Polsce. Rekonesans}

$\mathrm{N}$

ieznaczne różnice dają poważne konsekwencje. To jak ze skrzydlem motyla, które podobno może wywołać tajfun. Wszyscy wiedza, że Chińczycy czy Japończycy jedzą paleczkami przedziwne potrawy, jak zgnite jajka, surowe ryby czy żywe dżdzownice. Że kiedy się uśmiechają, to być może nienawidzą. Że są wręcz zniewoleni przez kult zmarłych i starszych od siebie. Jest to traktowane jak egzotyka i nie przeszkadza w kontaktach, a przynajmniej nie słuzy do wydawania ocen. Inaczej jest z kulturami bliskimi, gdzie różnice manier, kodeksu grzeczności, zachowań - nie rzucają się w oczy. Wydaje się nam wtedy, że możemy odczytywać zachowania bliskiej kultury wedhug tych samych kryteriów co nasze - bardzo często zresztą na poly tylko uświadamianych, czy wręcz nieświadomych. Nasze reakcje kulturowe są bowiem w olbrzymiej mierze - niektórzy mówią o 80 procentach, inne o jeszcze wyższych liczbach — odruchani warunkowymi wyrobionymi przez pokolenia'. Śmiejeny się, gdy opowiadają, że w Afryce bekanie należy do dobrego tonu; opowiadany sobie dowcipy o polskim chłopie, który się czuje niezdrowy, kiedy nie ma gazów (przepraszan za drastyczność); ale nie umiemy sobie wytłumaczyć odruchu zniecierpliwienia na twarzy Anglika, Francuza czy Niemca w codziennych, milych nieraz sytuacjach; tak jak i my ze zdziwieniem patrzymy na niektóre jego zachowania. W dodatku ewolucja po 1989 roku idzie w Polsce raczej w kierunku rozpowszechniania obcych, modnych wzorów, jak i ,postmodemistycznego" mieszania ich między sobą.

\footnotetext{
I Z bogatej literatury ctologiczncj. która stanowi podstawę metodologiczną tego szkicu. wy'mienić chę̧ tylko lingwiste Noama Chomskicgo (Langugge and . Mind. New York 1968). prace biologa Konrada Lorenza (zwłaszcza Odurotna strona zl'ierciadta. Warszawa 1977). Desmonda Morrisa (przede wszystkim Mammeathing. New York 1977), i prace zbiorowa pod redakcja Juliana I Iuxkya Ritnalisation of beflarior in animals and man (1966). wyd. francuskic: Paris, Gallimard. 1971.
} 
Dziedzina jest olbrzymia i mało badana. Pozwolę sobie na zebranie paru spostrzeżeń dotyczących manier przy stole we Francji i w Polsce, z okresu sprzed wielkich przemian, by na tych przykładach pokusić się o jakieś prowizoryczne uogólnienia. Chodziło będzie o opis modelowy - wedlug weberowskiego pojęcia „modelı idealnego” — czyli bez socjograficznych czy statystycznych danych, choć oczywiste jest, że zawsze chodzi o pewne normy - reprezentowane w Polsce lat sześćdziesiątych do osiemdziesiątych przez tak zwaną inteligencję, a we Francji przez tak zwanych funkcjonariuszy, czyli spadkobierców noblesse de robe Ludwika XIV. Po 1989 roku stratyfikacja społeczna i kulturowa w Polsce uległa ważkim przesunięciom, i dopóki się na nowo nie skrystalizuje, nie zawsze inteligencja będzie „nadawać ton”. Niemniej wciąż występują różnice strukturalne między omawianymi kulturami — choć nie przez wszystkich dostrzegane ${ }^{2}$.

Najpiew, ,na przekąskę", parę obrazków. Otóż należy do dobrych manier w Polsce krajanie chleba, który zresztą przeważnie produkowany jest w bochnach i trudno sobie wyobrazić inne wyjście. Natomiast śmiejemy się z prostackich manier chłopa, który ulamuje sobie chleb po kawałku. Dokladnie na odwrót jest we Francji. Oba sposoby też istnieją, ale prawie że symetrycznie są inaczej nacechowane: należy bagietkę przy stole łamać po kawałeczku, jak najmniejszym zresztą, a jessli nawet nakladamy na te kawaleczki na przykład ser, to winny być wielkości kęsa. Natomiast krajanie chleba traktowane jest jako prostactwo - chyba ze chodzi o chleb „specjalny” w bochenkach. Ale nawet wtedy w zasadzie należy urywać sobie z kromki po kawałku. Wyjątkiem jest śniadanie, o czym za chwilę, oraz gotowe kanapki, czyli sandwicze.

Inny przyklad: jabłko. Chętnie gryziemy jabłko bezpośrednio, obierajaje uprzednio tylko osoby niewychowane i bezzębni starcy. Uchodzi to we Francji za prostactwo - należy jabłko czy inny owoc, zwlaszcza przy stole, obrać, i dopiero po kawaleczku zjadać. Powiemy sobie: odwrotność zachowania z chlebem. Z jednej strony żywiol, z drugiej „kultura”. Ale w Polsce też układa się to na odwrót...

Trzeci przykład. Zapewne ze względı na zwyczaj pijania wina przy stole, we Francji nie wolno pijać „z pełną buzią”, czyli trzeba najpierw przełknąć, a dopiero potem popić. W Polsce na odwrót. Różnica jest szczególnie dotkliwie widoczna przy śniadaniu. Polak chętnie ugryzie spory kęs chleba i będzie rozmaczał go w ustach herbatą czy kawą. Jest to szczególnie smakowite, kiedy dzieci rozmaczają na przyklad kawalek ciasta czekoladą czy kakaem. Horror dla Francuza. Za to będzie tolerował - choć jakby nie zauważając tego, na pól oficjalnie - maczanie bagietki w porannym bolu kawy. I to nawet bagietki posmarowanej masłem, tak że po powierzchni kawy będą plywały tluste ,oka”. Polak odwróci od tego wzrok ze zgrozą, nie śmiejąc nic powiedzié, ale co sobie pomyśli, to pomyśli.

Oto trzy przykłady trochę bezladnie podane, ale to, jak powiedzieliśmy, ,.na zakąskę" czyli aperitif. Postaramy się teraz podejść do sprawy bardziej systematycznie.

\footnotetext{
2Przypomina mi to rozmowę mcj francuskicj zony z bliską krewną w Polsce. Mowa byla o tym. że we Francji ludzie calują się w policzki. w Rosji w usta, a w Polsce często w rodzinie w kącik ust. Polka oburzyła się: ,Jak to, ja nigdy nic caluję. nawet w kącik ust!" - wykrzyknç̧ła. Po czym, na pożcgnanic, ucałowala moją żonç w kącik ust.
} 


\section{Rytuały picia}

Wiadomo, że krazży we Francji malo pochlebne dla nas powiedzenie .pijany jak Polak”. Chodzi oczywiście o kogoś pijanego w sztok. Thumaczyny, że znaczenie zostało przeinaczone, że chodziło o wojny napoleońskie, o walki z I Iiszpanami, w czasie których cała armia upila się po zwycięstwie, ale tylko Polacy potrafili potem dać odpór wycieczce Hiszpanów. I wielki wódz miałby wtedy powiedzicć „Panowie, bądźcie pijani jak Polacy!”, to znaczy: nie tracąc umiejętności bicia się, zachowų̣ąc trzeźwość. I tylko zawiść i zła wola oficerów francuskich przeinaczyly to pierwotne znaczenie.

Jak tam bylo pod Saragossa - nikt nie wie; ale powiedzmy nczciwie: czy nawet gdyby to była prawda, powiedzenie przyjęloby się, gdyby nie odpowiadalo pewnej rzeczywistości? Więcej - pewnej filozofii picia, zakorzenionej w kulturze.

Bo nie ma co się oszukiwać - Polacy nie piją codziennie, tylko przy specjalnych okazjach (poza alkoholikami), ale jak już piją, to lubią to poczuć. Wspólczesna literatura, od Hlaski przez Konwickiego do Stasiuka, moglaby tu dać wystarczająco wiele przykladów. A jak nie literatura, to opracowania socjologiczne. Zamiast więc mydlić sobie oczy, spróbujmy zrozumieć, dlaczego Polak lubi się upijać - kiedy już pije, to wręcz chce się upić? Najlepiej oddaje to żargonowe powiedzenic w sytuacji, kiedy się tylko zaczęlo pić, bez przewidzianego dalszego ciaggu: „skaleczyć się”. A każda rana potrzebuje opatrunku.

Osobiste, prowadzone w młodości z całym oddaniem nauce studia eksperymentalne autora niniejszego szkicu, jak też liczne świadectwa literackie wskazıją, iz Polacy nie dążą celowo do zawrotu glowy, wymiotów, przetraconych pieniçdzy i innych nieprzyjemnych konsekwencji tego obyczaju, czyli — poza alkoholikami - niekoniecznie traktują wódkę jak narkotyk, a raczej jako okazję do wspanialych kontaktów międzyludzkich, do bezpośredniego „czucia”, „poczucia” czy „wyczucia” drugiego czlowicka, do zwarcia dusz i ducha, który można by nazwać komunią międzyludzką. Tak budują swój kościól międzyludzki (nie przez przypadek „kaplan niższy” w Ślıbie (Gombrowicza nazwany jest Pijakiem), gdzie rytual picia jest wymienny z „nocnymi rodaków rozmowami”, toczonymi pod blogosławieństwem wieszcza przynajmnicj od czasu rozbiorów (świadectwo Kochanowskiego i przeżycia l)oktora I Iiszpana wskazywałyby na dłuższą tradycję).

Specjalne miejsce w tym rytuale zajmuje Kobieta - poprzez swoją niéobecność. Picie jest bowiem sportem przede wszystkim męskim, i jeśli nawet zaczyna się w towarzystwie kobiet (na przykład podczas świąt religijnych czy imienin), to następnic udany seans picia kończy siç wyłącznie w towarzystwie jednoptciowym. Ale wtedy kobiety pojawiają się in absentia - jako przedmiot rozmów. Ba, nie tylko rozmów, czy nawet zwierzeń, ale jako przedmioty szczególnego i specyficznego kultu. Bowiem proporcjonalnie do ilości spożytego alkoholı wzrastają wyrzuty sumienia, przychodzą na myśl wydane pieniądze, własny niezzbyt godny clrwały stan, i wreszcie wspomnienia, jak to się zazwyczaj koniczy. A kończy się źle — trudnościami z trafieniem do donu, niechcianą „wylewnością”, by tak to określić, i wreszcie zetknięciem z wyższą 
rzeczywistością moralną, to znaczy z matką, siostrą, żoną czy córką. Czyli z własną duszą ${ }^{3}$. Niektóre co prawda tracą spokój, co jest zrozumiałe, ale motyw najczęściej powracający w prowadzonych - by tak to nazwać - wywiadach, to anielski spokój, wyrozumiałość kobiet, skrywany smutek... I dobroć, potworna dobroć, monstrualna dobroć, spychająca mężczyznę na dno moralnego ponizenia.

Można by się zasadnie spytać, skąd ów wstyd, skoro chodzi o kulturową normę? Dlaczego poczucie winy? Rytualy zazwyczaj, wręcz przeciwnic, dają poczucie specyficznej satysfakcji, jeśli wierzyć etologom ${ }^{+}$. Otóż prawdopodobnie chodzi o konflikt dwu typów norm. Polacy żyja „oficjalnie” w cywilizacji europejskiej, pracują, zarabiają, utrzymują rodziny... To wszystko w dzień. W niedzielę chodzą w większości do kościoła, i słuchają nauk moralnych o dobrodziejstwach trzeźwości i pracy. Ale przecież prawdziwe życia Polaka zaczyna się w nocy, najwymowniejszym obrazem tego jest $W$ csele Wyspiańskiego. Rzeczywistość dnia jest zlem koniecznym, trzeba udawać, że się w niej uczestniczy, ale serca się w to nie wkłada. Dlaczego? Może z powodu rozbiorów i rozmaitych okupacji, a może samatyzmu jeszcze i anarchii Pierwszej Rzeczypospolitej. A może to odzywa się „dusza słowiańska”? Na razie nie będziemy tego rozstrzygać, ponieważ wymagałoby to poglçbionych studiów u wschodniego sąsiada, na co autorowi nie pozwala stan wątroby. Trzeba jednak stwierdzić fakty: w nocy i w stanie upicia Polak Polakowi bratem, ojczyzna staje się rzeczywistością czasem wizyjną tylko, jak « Wyspiańskiego, ale też relacjonalną międzyludzką przestrzenią. Faktem. „Piję, piję bo ja muszę” wyznaje Nos, i dodaje: „Gdyby Chopin żyl, to by pił!”. A dlaczego Chopin nie pil, to znaczy nie upijal się? Czy wtedy jeszcze tak nie pito? Świadectwo Pana Tadeusza zdaje się temu przeczyć. Może byl chory? - biedny człowiek. A może po prostu za dlugo przebywat we Francji?

Bo Francja nie przeżywa schizofrenicznego rozdzialu na dzień i noc, co nie znaczy że Francuzi wcześnie się kładą spać. Wręcz przeciwnie. Dlatego, że noc stała u nich kolonią dnia. To znaczy została podporządkowana wszystkiemu temu, co dzień reprezentuje: jasnej inteligencji, poczuciu rzeczywistości, intensywnemu przeżyciu każdego wydarzenia. Francuzi tė̇ piją, i to dużo. Codziennie. W Polsce picie codziennie jest znamieniem alkoholizmu, a więc większość Francuzów za takich by mogła w Polsce uchodzić. W przeliczeniu na czysty alkohol piją bodaj więcej niz Polacy, jeśli w ogóle takim badaniom wierzyć. Ale piją inaczej.

Piją codziennie przy jedzeniu. Popijajajedzenie, czego Polacy nie robią. Ale na ogół nie piją wiele, bo nie chodzi o upicie się, a o smakowanic świata, o jak najintensywniejsze przeżywanie rzeczywistości. Właśnie, lubią smakować to, co piją. (W odróżnieniu od Polaków, co wyraża słynne powiedzenie: „wódka to mój wróg, więc go w mordę leję”). Francuzi mnożą więc

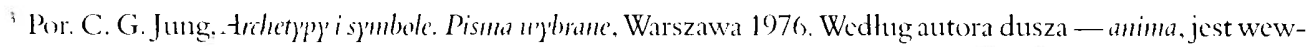
nçtrznym obrazem ukochancj. uformowanym przez figuruç matki, ale odzwierciedlającym potem równicż siostrę, zonç. córkę...

Por. K. Lorenz. Tik zirane = to. Warszawa 1972, rozdz. 5. Każdy rytual wytwarza wedlug autora „cechy zachowania siç apetytywnego, tzn. przcmożnego dązenia do wytworzenia takicj sytuacji wyzwalającej, w której spiçtrzony instynkt móglby siç rozladować" (s. 104). Prace innycl ctologów (Huxlcy. Erikson...) w petni potwierdzają obscrwacjc Lorenza.
} 
smaki. Rytuał jest często obecnie upraszczany ze względu na rytm życia, ale dawniej pełna paleta trunków przy biesiadnym posiłku to był najpierw aperitif - na apetyt (tradycyjnie słodkie gotowane wino, pastis lub cydr, obecnie też whisky, piwo lub wódka z sokiem pomarańczowym). Potem przy stole, zależnie od potraw, białe wytrawne wino do ryby, stodkie biale wino (na przyklad Sauternes) do foic gras, porto do melona... Przy pieczystym obowiązywało czerwone wytrawne. Przy deserze powracalo slodkie biale wino, a po kawie podawano tak zwany digestif, czyli cośna strawienie. Byl to przeważnie koniak, ale mógł też to być inny destylowany z owoców alkohol jak calvados, kirsch lub poire. To wszystko - przy obfitym jedzeniu i konwersacji, która wymagała pewnej lotności umysłu (wrócimy do tego) - nie upijało, lecz utrzymywało umysł w stanie przyjemnego rauszu: życie wydawało się piękne, kobiety ponętne (dla kobiet — mężczyźni pociągający), życie pasjonıjące, sprawy tego świata zrozumiale i reguły gry jasne. Dobrym przykladem sily tego modelu była uprzednia norma alkoholu we krwi dopuszczającego prowadzenie samochodı: (),8 promila (w Polsce 0,2). To znaczy, że do posilku można było wypić pół butelki wina, albo aperitif i kieliszek wina, albo kieliszek wina i koniak... Obecnie norma jest surowsza: 0,5 promila, ale też pozwala na dwa kieliszki wina przyjedzeniu (dla kobiet - jeden kieliszek). Co jest nawet medycznic wskazane, jak się ostatnio z badań - amerykańskich — dowiedzieliśmy.

Mamy więc z jednej strony rytualną ucieczkę z tego złego świata w lepszy, cudowny świat braterstwa, przyjaźni, miłości nawet, świat marzeń i (niezrealizowanych) aspiracji, świat głęboko więc chrześcijański... jako marzenie (a nie rzeczywistość), i jako rzeczywista duchowa komunia. A z drugiej strony - co też jest mitem — świat racjonalny, podporządkowany woli człowieka, słuzą̨cy mu - przynoszący satysfákcję i indywidualne przyjemności oraz poczucie piękna, który działanie alkoholu czyni intensywniejszym. Świat który zachęca do życia, do dzialania, do pełnej sprawności. To dlatego zresztą we Francji jest bodajże najwięcej wypadków samochodowych w Europie wynikających nie ze złego prowadzenia, ale ze zbytniej pewności siebie, zwłaszcza pod wpływem alkolıolu. Nawet jeśli to się powoli zmienia — wrócimy do tych procesów - zdaje się to wyrażać tak zwany charakter narodowy.

Jeszcze jedno. Rytual picia jest w Polsce rytualem szczerości. Może nie w tym stopniu co w Rosji, gdzie upicie się jest wręcz świadectwem braku szczerości, i w czasach stalinowskich mogło podobno prowadzić prosto do śmierci, ale jednak tendencja ta też się daje zauważyćs Jest to logiczne — duże ilości alkoholı wykluczają ukrywanie czegoś, bo to wymaga pełni inteligencji. Za to wyzwalają spontanicznią żywiołową ennocjonalność. We Francji, gdzie emocjonalność jest inaczej kanalizowana, picie, wręcz przeciwnie, może stanowić element gry uwodzenia w stosunkach międzyptciowych, intrygi w pracy, oszukiwania w interesach. Bo podekscytowany unysł pozostaje jasny, a życie przedstawia się jak partia szachów, wszystko sprawia przyjemność, a przegrana czy wygrana jest ograniczona przez pewne niepisane poro-

\footnotetext{
${ }^{5}$ Por. T. Torańska. Oni, Londyn, wyd. Ancks, 1985: zwlaszcza rozdzial o Jakubic Bermanic. Zwyczaj sprawdzania szczerości odpornością na upicie siç przetrwal do końca komumizmu. jak na to w'skazujją zwierzenia prywatnc bylego sekretarza wojewódzkiego, który musial przygotowywá́ siç dlugo naprzód na przyjmowanic towarzyszy radzieckich, a stanowisko swe zawdzięczal w duzicj micrze silncj głowie.
} 
zumienie nieprzekraczania pewnych granic. Polacy w intrygach granic nie znaja, tak jak w alkoholu, a gry prowadzą bez przyjemności, jak z obowiązku. Ale wtedy się nie upijają. Czyli alkohol bylby istotnie jakąś gwarancją szczerości...

\section{Rytuały jedzenia}

W kompozycji biesiadnego posilku we Francji, a nawet w codziennej praktyce, uderza proporcja dania głównego w stosunku do dodatków. Jakby Francuzi nie tyle chcieli się najeść, co jeść - odprawić rytuał. Dodatki wydają się ważniejsze niż sytność posiłku. Mało kto wyobraża sobie obiad czy kolację bez serów czy bez deseru — najchętniej ciastka (bez kremu, we Francji to przeważnie jabłka czy imne owoce - gruszki, rabarbar, truskawki, maliny, śliwki, morele - upieczone na tak zwanym francuskim cieście). Podobnie z aperitifem — teoretycznie odświętny, praktycznie pije się go, kiedy się da - w każdej restauracji kelner od tego rozpocznie obsługę, czasem aperitif ofiarowany jest przez whaściciela... Przystawki w poludnie to często surowe jarzyny lub sałata, czyli coś lekkiego, ale bez nich jest jakby pusto na talerzuı... Francuzi to wprawdzie nie „straszni mieszczanie” Tuwima, którzy widzą wszystko oddziehnie, ale oddzielnie lubią jeść: surówki czy sałatę najpierw czy po daniu głównym; a w wielı regionach do niedawna podawano jeszcze osobno mięso (czy rybę) i osobno jarzyny. Jak gdyby chciano wydłużyć przyjemność. Daleka od funkcjonalności, czynność jedzenia jest też uprzywilejowanym monentem spotkań, wspóludziałem w rytuale radości życia.

Ale Francuz musi widzieć i wiedzié́, co je. Przerażony jest bigosem, jeśli zbyt rozgotowany i nie widać, co w tej masie plywa. Natomiast jeśli wyłowi grzyba, kawałek mięsa czy kielbasę, od razu wzrok mu się rozjaśnia. Najchętıiej jadłby to wszystko osobno, po kolei; osobno, nawet jeśli podane na jednym talerzu, bo wtedy czymność poznawcza wzmacnia i utrwala wrażenia smakowe, a wszak konsumuje się nie tylko potrawy, ale i ich symbolikę...

Przeważają we Francji mięsa pieczone. I tu znowu proporcja międ zy naturą i kulturą różni Polskę od Francji. Czerwone mięso - wołowinę czy baraninę — większość Francuzów woli na pól surowo. Czasem nawet środek pieczeni baraniej jest ledwo letui - to tak zwane mięso „czerwone” lub „niebieskie”. Polaka to na ogół odrzuca, woli dobrze uduszone mięso, które rozplywa się w ustach prawie bez gryzienia. Co mu nie przeszkadza zreszzą zjeść od czasu do czasu tatara - mięsa zmielonego. Polak niekoniecznie chce widzieć i wiedzieć — chce poczuć.

Jakość mięsa jest niezwykle we Francji ceniona. To bodaj jedyny kraj, który importuje mięsa zadnie (udźce, polędwice), a eksportuje przednie. O sztuce wykrawania poszczególnych części z wołu polski rzeźnik nie może nawet marzyć, a słowniki polskie nie mają dość określeń. Wiadomo z góry — z kultury — która część jest „,soczysta”, która „nabita” (ferme), ale pehar smaku, która z kolei żylasta i ma befszztyk się nie nadaje, a tylko do duszenia czy gotowania. Nie trzeba mówić, ze ceny są tu obiektywnym wskaźnikiem preferencji kulturowych, i że na przyjęciach ocenia się również jakość i wartość podanych mięsiw (czy ryb). 
Ciekawe, że inna jest hierarchia w obu kulturach. W Polsce najwyżej jest ceniona wieprzowina, potem cielęcina, wolowina... Baraniny więckszość Polaków nie chce nawet jeść, dlatego też zniknęła ze sklepów, mimo że pieczeń barania z czosnkiem i z buraczkani była tradycyjnie jednym z narodowych przysmaków. We Francji baranina, a przede wszystkim jagnięcina są cenione najwyżej, i w związku z tym są najdroższe. Potem wołowina, cielęcina, ina samym końcu dopiero wieprzowina. Znowu ta sama opozycja: czerwone mięsiwo to dla Francuza smak życia; thuste prosię dla Polaka - na przykład golonki - pozwala poczuć się nasyconym (i poza tym stanowi znakomity podkład do wódki)".

We Francji cennicjsze od mięsa są ryby. Niektóre są tak drogie, że trzeba być naprawdę zamożnym, by sobie na nie pozwolić (a w Polsce pamiętany z czasów gomulkowskich powiedzenie ,jedzcie dorsze, g... gorsze!”). No i dania regionalne, to znaczy specyficzne, oryginalnie przyprawione. Jak foie gras, canard confi (czyli kaczka wolno pieczona w swym tłuszczu), czy też coq au ı'in (kogut duszony w winie). Poszukiwany będzie nade wszystko wyrafinowany smak - im oryginalnicjszy, tym lepicj; w Polsce najwyżej ceniona jest syntetyczność smaku i faktura jedzenia, które ma się „rozplywač” w ustach. Bo jedzenie to nie praca i nie walka wbijanie zębów w krwistą rzeczywistość, jak we Francji - a błogi stan sycenia się, dający poczucie bezpieczeństwa.

To wszystko jednak dopiero punkt wyjścia; najważnicjsze są maniery, czyli sposób jedzenia... Otóż trzeba zacząć od zaproszenia. W słynnej z gościnności Polsce, zwłaszcza w stosunku do przyjaciól, przyjęte bylo „wpadanie” bez zapowiedzi albo po krótkim telefonie, i wtedy „czym chata bogata, tym rada”. Zawsze i o każdej porze dnia można ofiarować herbatę z cytryną albo bez, i jakieś herbatniki. Korzystal z tego zwyczaju Żeromski - w okresach biedy odwiedzał znajomych i wsypywal sobie do herbaty wiele tyżeczek cukru; przeżył w ten sposób trudny okres głodowania.

Przychodzi się też bez zapowiedzi na imieniny, i wtedy przeważnie nie ma dań przyrządzonych na gorąco, a tylko sałatki, wędliny, ryby wędzonc itd. - niekończące się zakąski. We Francji zaproszenie do domu jest uzyskać trudno. Ratowani przez francuskich intelektualistów dysydenci nigdy nie zostali zaproszeni przez Gide’a czy Sartre'a, co niektórzy bardzo źle zuosili ${ }^{7}$. Ale jeśli już wizyta ma mieć miejsce, to trzeba zapraszać dhugo naprzód, czasem nawet na wiele tygodni czy miesięcy z góry. I wtedy przyjęcie musi być perfekcyjne. Cenny będzie dobór win, przystawek czy mięs (ewentualıie ryb), ale równie ważna będzie praca włożona w ich przyrządzenie. I oryginalność mentn. Bowiem jest to konkretny wyraz szacunku, jaki mamy dla gości. Czyli nic na łapu-capu, wszystko skomponowane jak dzieło sztukirównież zastawa, i oryginalny smak, który się będzie dlıgo pamiętać, czasen notować w dzienniku, a jeśli chodzi o panią domu — utrwalić tak, żeby następnym razem już nigdy nie podać tym samym gościom tej samej potrawy. 1)awniej (jeszcze z trzydzieści-czterdzieści lat temu) wynajmowało się do przyjęć kelnerów, niby lokajów, którzy zajmowali się podawa-

\footnotetext{
" Należy odnotować, że pieczona golonka jest też bardzo popularna w Alzacji i Lotaryngii.

'Por. H. Lottman, La Rive gauche, Paris, Seuil. 1981.
} 
niem pólmisków i dolewaniem wina. Są to obyczaje znane również polskiej arystokracji w XIX wieku, ale we Francji o wiele bardzicj zdemokratyzowane.

Zasadą podawania - jak już była nowa - jest rozdzielność. W czasie wytwornych posilków na olbrzymim talerzu jest tylko mięso albo ryba i ślad jarzyı, za to specjalnie przyprawionych. Nie ma nowy o talerzu przepelnionym mięsem, kartoflami i sałatką jednocześnie. Toczy się rozmowa — nie ma mowy, by goście, jak w Panu Tadeuszu, „milczkiem żwawo jedli”, byłby to szczyt złego wychowania. Rozmowa ma być interesująca - lekka, blyskotliwa, dowcipna, świadcząca o wyższości umystu zebranych, o ich polocie. W czasie takiej rozmowy można się skompromitować na cale życie, albo wręcz przeciwnie, zyskać uznanie, które zadecyduje o przyszlej karierze. Dość dobrze rytuały te opisal Proust ( $W$ stronę Su'anna). Rozmowa może dotyczyć też dań i zwłaszcza win - nieznajomość sekretów podniebienia, zwłaszcza gdy chodzi o trunki, jest kompromitująca.

Przy stole siedzi się długo — nie ma mowy, by najeść się i zniknąć. Jedzenie, jak już mówiliśmy, to pretekst do spotkania, atmosfera się rozgrzewa - choć może nie aż tak, jak w filmie Uczta Babette. Czyli spotkanie międzyludzkie, które w Polsce osiąga się przez wódkę, tu jest raczej efektem dań. I rozmowy. Nawet natury skryte bowiem i oziębłe rozluźniają się w czasie poświęconym przyjemnościom podniebienia i unnysłu, i zaczyna panować atmosfera serdeczności. Nie jest to jednak „komunia” duchowa, jak w Polsce, raczej chodzi o wymianę intelektualną i emocjonalną międ zyludzką poprzez uczestniczenie w tym samym rytuale, jakby przez indukcję, bo kultura indywidualistyczna wymaga panowania nad sobą intelektualnie i wolitywnie, nie ma mowy ani o poszlacheckim "popuszczaniu pasa” ani o osobistych wynurzeniach. Ale pewna doza serdeczności jest w ramach bardzo trudnych stosunków międzyludzkich we Francji i tak niemal cudem, i spotkania przy stole dhıgo się wspomina, czasem cate życie.

Fakt też, że się jadlo przy jednym stole (w domyśle - uczestniczyło się w atmosferze wzajemnego kontaktu), jest znaczący dla kariery, stosunków, wpływów. Społecznego uznania. Jest to osobowe spotkanie, którego się nie zapomina.

Tym ważniejsza jest rola pani domu. To ona rozsadza gości, prowadzi konwersację, tworzy atmosferę. Wprawdzie pan domu kraje mięsiwo i rozlewa trunki (nie do pomyślenia jest wyręczenie go w tej czynności!), ale pani domm odpowiedzialna jest za jakość przyjęcia. Tym dziwniejsze jest, że przeważnie nie zajmıje miejsca u szczytu stołu, jak w Polsce, chyba że wiek ją do tego dodatkowo predestynuje. Glówne miejsce zajmuje pan domu albo jakaś osoba szczególnie ceniniona.

To wtedy, gdy chodzi o przyjęcia. Na co dzień oczywiście wszystko jest mniej ceremonialne - w obu krajach. Pozostaje jednak podstawowa różnica - godziny posiłków. Święte we Francji, zachowywane są nawet w dość wyjątkowych okolicznościach - w poludnie przedsiębiorstwa przerywają pracę, drogi pustoszeją, a dzieci często wracają coś zjeść do domu. Godziny są następujące: śniadanie (petit déjeuner, czyli „małe co nieco na poczucie czczości”) rano składa się przeważnie z kawy z mlekiem (lub herbaty) i kawalka chleba z konfiturą albo rogalika (croissant). Obiad (dëjunter, co właściwie znaczy ,śniadanie”) jest jedzony okolo dwuna- 
stej-trzynastej. Bez zupy, lżejszy więc znacznic od obiadı polskiego, składa się zazwyczaj z przystawki, dania glównego, salaty, serów albo/i deseru i kawy. Wszystko po kolei, nic razem. Za to kolacja (dîncr, wlaściwie ..obiad”), jedzona jest na ogół później niż w Polsce — około dwudziestej-dwudziestej pierwszej, i jest obfitsza. Na wsi często je się zupę, w mieście na ogól tak jak w południe, chó́ zupa też się zdarza zamiast przystawki ', ale wszystko obficiej i wolniej. To na co dzień. Wszystko jednak ewoluuje, i posiłki wieczorne też stają się teraz coraz lżejsze — jak w Polsce; gdzie na co dzień kolacja sprowadza się przecież najczęściej do kilku kanapek z herbatą. Charakterystyczne, że francuskie nazwy wskazıją na arystokratyczny tryb życia, gdy rano wypijało się tylko kawę, wstawało się do posiłku w połıdıie, za to kładziono się duzo później spać. Istnieje też we Francji stary zwyczaj „podkurka”, zwanego soupcr.

W niedziclę i święta jest uroczyścicj, często idzie się do restauracji z całą rodziną. Restauracja służy też do „dîner d'affaires”, czyli posilków roboczych, które pojawily się po 1989 roku i w Polsce. I wtedy wybór restauracji i posiłku jest wprost proporcjonalny do wysokości kontraktu czy wagi sprawy. Istnieją więc najdroższe restauracje, gdzie w zasadzie można spotkać tylko biznesmenów czy reprezentantów wielkich przedsiębiorstw. Tam to, ,między gruszką i serem" (entre la poire et le fromage) — w momencie największego rozluźnienia i serdeczności, gdy wszyscy są zadowoleni z posilku, z życia i z siebie wzajemnie — załatwia się najtrudniejsze negocjacje i konkluduje przymierza.

Gdyby postarać się o sformułowanie najogólniejszej zasady dla każdej z omawianych kultur, trzeba by podkreślić arystokratyczny charakter matryc francuskich, a dużo bardziej .demokratyczny” - w sensie zapewne „demokracji szlachechiej” — manier polskich, o wicle mniej sformalizowanych (Gombrowicz się kłania). Z jednej strony wyrafinowanie i „esprit”- blyskotliwą inteligencję, z drugiej ciepło, bezpośredniość i szczerość kontaktów międzyludzkich, no i ..pyszne jedzenie”, co niekoniecznie oznacza wyrafinowanie. Rozmowa przy stole też w Polsce jest ważna, ale jak się wydaje, ma modelowo inny charakter — bardziej osobisty, gawędziarski, przyjacielski. Bo nawet jeśli w XIX wieku — jak pisze Krystyna Bockenheim -

...ostatecznie zwyciężyła kuchnia prosta, chudopacholska, rodem z czasów

Rzepichy, nie ze stołów barokowych wielmoży"

— gościnność i typ atmosfery emocjonalnej z pewnością ma swe korzenie w czasach saskich.

\section{Oznaki uprzejmości}

Wizyta rozpoczyna się od powitania. W Polsce praktycznie obowiązuje całowanie w rękę kobiet, starych i młodych, ladnych i mniej atrakcyjnych — wszystkich, i biada tym, którzy

\footnotetext{
* Jak wskazują dokumenty. dawnicj też jadano w Polsce zupę wieczorami. Por. fragment wspomnień Stanistawa Morawskicgo z Wilua z początku XIX wicku, gdzic wystawna kolacja skladała się z tizech zup: barszcz z wedliną, krupnik z wędzonym podg̨̧̧skicm i kleik owsiany ze śledziem (sic!) (Zob. I. Jarosińska. Kudmia polska i romantyezma. WL. Kraków 1994, s. 172).

${ }^{4}$ K. Bockenhicim, Priy' polskim stole. Wroctaw 1999, s. 121.
} 
usiłują się od obowiązku wywinąć... Zwyczaj ten przywędrował z Francji, ale tam od dawna praktykowany jest tylko w arystokratycznych sferach lub w dyplomacji, i jest gestem tylko, manifestacją intencji raczej niż rzeczywistym pocalunkiem: mężczyzna unosi ku wargom rękę kobiety nie dotykając jej ustani. Tym bardziej, że dawniej kobieta z reguły nosiła rękawiczki. W Polsce calowanie w rękę, zwłaszcza młodych i ladnych kobiet, jest niemalze sportem erotycznym, ale przede wszystkim sam gest jest inny i inaczej krystalizuje zasady relacji: mężczyzna pochyla się ku ręce, która pozostaje na swej naturalnej wysokości, i rzeczywiście całuje wyciągniçtą dloń. Gest francuski natomiast odpowiada słownemu wyrażeniu "rendre hommage": mężczyzna, nawet czyniąc gest hołdu, pozostaje wyprostowany, a kobieta unosi dłoń. Mężczyzna zachowuje pozycję dominującą. W Polsce gest pochylającego się mężczyzny wyraża nie tyle hold, co podległość, gotowość podporządkowania się, podczas gdy wyprostowana kobieta jest może nie jak bogini, ale przynajmniejjak wielka dama w towarzystwie czlowieka niższej kondycji. Czy to thumaczy popularność Lalki Prusa? - bo taka wlaśnie jest relacja Izabelli do Wokulskiego. (Usiłujenny oczywiście schematyzować, nie określa to stosunków osobowych, a tylko modele kulturowe zachowań).

Od jakiegoś czasu — powiedzmy: od wejścia w życie pokolenia 68` - we Francji rozpowszechnił się pocałunek w policzki, i to zarówno wśród mlodych, jak i wśród starszych, wśród kobiet, jak i w towarzystwie mieszanym, a nawet wśród mężczyzn w środowiskach artystycznych. Wyraża on tam przezwyciężenie konwencjonalnego podziału na płci i określania specjalnych zachowań dla kobiet. (W środowiskach tych nawet niebezpiecznie jest ofiarować kwiaty kobiecie, bo się uchodzi od razu za „maczistę” [od hiszp. macho], czyli ideologicznego samca.

Pocałunki w policzki są dużo łatwiej i szerzej rozdawane niż w Polsce, i widziałem niejedną młodą i ladną Polkę przerażoną tym spoufalenienn, które odbierała jako gwalt psychiczny. W Polsce takie pocałunki męsko-damskie związane są w o wiele większym stopniu z pewną erotyką. We Francji jedynie pocałunki w usta mają charakter erotyczny i zarezerwowane są do sytuacji specyficznych. Dlatego zapewne, by uniknąć jakicjkolwiek ambiwalencji, zwłaszcza mlode Francuzki nie tyle calują się nawzajem, co powietrze wokól - przyciskając swe policzki jeden do drugiego.

Mimo pozornie zupełnej swobody pocałunków w policzki, tu też panują niepisane reguły. Całują się po pierwsze równi z równynni: koleżanka z koleżanką albo koleżanka z kolegą, żona ministra z żoną ıninistra, działacz partyjny z działaczką partyjną itd. Nie spostrzega się prawie pocałunków z załamaniem hierarchii społecznej, mimo obowiązującego egalitaryzmu. Czyli: „obserwuj, kto kogo caluje, a będziesz wiedzial, jaka jest jego pozycja”.

Możliwe są też pocałunki - by tak rzec - wertykalne, czyli osoba starsza z młodszą, wyżej postawiona z podwladnym (-a) itd. Za każdym razem jednak jest to wyjątkowy gest dobrej woli, życzliwości czy wręcz chęci pomocy psychologicznej dla kogoś - biedaka — w pozycji podporządkowania. Czyli trochę gest feudała w stosunku do swego wasala (przesadzając oczywiście dla potrzeb eksplikacji). 
Tak więc przy wizycie, juz w momencie powitania rozpoczyna się balet slów, gestów i uścisków. W obu krajach, ale o wiele bardziej znaczący jest każdy gest we Francji. To mi przypomina znakomity komentarz Boya do francuskiego thumaczenia Pana Tadeusza, kiedy to rozważał on, jak Francuzi zrozumieją sytuację salonowa, w której bohater kopnąl krzesho, splunął na podłogę i wyszedł trzaskając drzwiami... a „szczęściem” nikt się nie spostrzegt "'! Rzecz nie do pomyślenia w salonie francuskim, gdzie nie tylko gesty i spojrzenia czy najmniejsze mrugnięcie, ale wręcz myśli i drgnienia duszy są natychmiast spostrzegane, interpretowane i notowane w pamięci. Znowu: z jednej strony poczuć się dobrze razem, a z drugiej widzieć i wiedzieć.

Wracając do powitania: mężczyźni w obu krajach ofiarowują kwiaty albo „cos” (na przykład butelkę dobrego wina, jeśli to przyjacielska wizyta) - pani domu. Niby podobnie jest w Polsce. Niemmiej w o wiele większym stopniu we Francji obowiązuje zasada rewanżu. Można nic nie przynieść, ale wiadomo wtedy, że nastąpi rewizyta. Nie do pomyślenia praktycznie jest, by ktoś był często zapraszany, a nie przyjmowal u siebie. Jeśli to biedny student, można uczynić wyjątek, ale nawet kawaler czy samotna kobieta zapraszają co jakiś czas do restauracji.

Po przywitaniach we Francji następuje aperitif. A więc nie siadają wszyscy od razu do stolu jak w Polsce, ale najpierw w fotelach i na kanapie. W salonie toczy siç rozmowa, w czasie której pani domu usiłuje dopilnować, by każdy mógl coś powiedzieć, i to coś interesującego dla wszystkich. Goście zresztą zostali tak dobrani, by mogli wymienić interesujące wiadomości czy uwagi. Dlatego też nie zaprasza się osób samotnych czy par — zawsze kogoś trzeciego na dodatek, najlepiej trzecią parę albo dwie osoby samotne. Bowien rozmowa jest ważniejsza niż jedzenie, nie wolno się rzucać na orzeszki i na trunki. Nie wolno sobie dolewać. Nie wolno samemu zajmować przestrzeni konwersacji - trzeba zostawić miejsce i czas innym, waloryzować to, co mówią. Rytual ten stanowi dokladne przeciwieństwo staropolskiego zwyczaju, gdzie każdy, po kolei i według społecznej hierarchii, snuł swoją opowieść-gawędę. Coś z tego pozostało i we współczesnej Polsce. We Francji obowiązuje wymiana słow i myśli w atmosferze przyjemności dla podniebienia i umysłı.

À propos „dolewania”: we Francji nie wolno, jak w Polsce, samemu sobie nalewać - wylącznie pan domu proponuje i podaje trunki, albo też ktoś przez niego o to poproszony, wyjątkowo pani domu. Jeśli chodzi o aperitif, na ogół, mimo propozycji, nie akceptıje się dolewania. Przy stole natomiast - odwrotnie niż w Polsce - dolewa się wszystkim po równo, tak, żeby nie bylo widać, kto ile wypił. I kiżdy pije w swoim rytmie, z wyjątkiem rzadkich toastów. W Polsce obowiąuje zasada, że nie wolno dolewać, póki kieliszek nie jest próżny — żeby nie zmuszać do picia. Ale też pije się toastami, wszyscy na raz i w zasadzie „do dna”. Trochę jednak do picia zmuszając...

Była juz mowa o skomplikowanej sztuce sadzania przy stole, oczywiście z zasadą przemienności kobiet i mężczyzn oraz rozdzielania par i małżeństw - co obowiązuje też i w Pol-

"Por. A. Mickicwicz, Pan Tade'lsz. ksiçga V. ww: 232-236. 
sce, choć mniej rygorystycznie. Znowu chodzi o to, żeby osoby siedzące obok siebie albo naprzeciwko siebie mialy sobie coś do powiedzenia. Dominuje zasada stołów niezbyt duzych jeśli jest za dużo osób, urządza się oddzielne stoliki, jak na przyjęciach oficjalnych. Nie jest to zasada przestrzegana w sposób absolutny, ale tendencja. Ostatnio modne są cocktaile albo bufety, które pozwalaja, przechadzając się, jeść i rozmawiać z różnymi osobani. Czyli znowuspotkanie i rozmowa są ważniejsze od jedzenia.

Tu Polacy mogą się oburzyć: jak to, my też spotykamy sic̨ przy stole przede wszystkim ze względu na wzajemmą sympatię, a niekoniecznie po to, by się najeść... Na to dam przykład spoza domeny przyjęć stricto sensu. Wyobraźmy sobie spotkanie - towarzyskie czy zawodowe - w kawiarni. Co zamawia się w Polsce, co we Francji? We Francji jedną rzecz na raz: kawę albo herbatę, albo sok, albo piwo, albo koniak... Można czasem w lecie zamówić do kawy wodę, ale często też podaje się wodę razem z kawą, jak we Włoszech. A w Polsce: i kawę, i sok, i koniak, i ciastho, i jeszcze może wodę mineralną... Obfitość jest znakiem życzliwości, naciska się wręcz na gościa, by się nie krępowat! Podobne zachowania można spotkać w całej Europie środkowo-wschodniej, gdzie obfitość jest znakiem życzliwości.

Podobnie trochę jest przy stole: w Polsce ilość i obfitość będ zie się równie liczyła co sympatyczna atmosfera, na końcu dopiero ważna będzie rozmowa. We Francji - rozmowa i wyrafinowane smaki, „sympatyczna atmosfera” jest ważna, ale wynika ona z zainteresowania osobami i aktem dzielenia z nimi przyjemnego wieczoru.

Istnieje ślad językowy tych zachowań, nieprzetłumaczalny na polski. Otóż istnieją restauracje i positki ,gastronomiczne” i normalne. „Gastronomiczne”, to znaczy wyrafinowane, rzadkie (w restauracjach gastronomicznych zatrudniony jest specjahnie wykształcony kucharz-artysta). Takie posiłki zapisuje się w dzienniczku i w pamięci. Są wydarzeniami w życiu. Jedzie się nawet kilkaset kilonetrów do słynnej restauracji - jak w Saulieu — wydając około 200 dolarów na osobę za nie najbardzicj wystawny posiłek, by za to poczuć sınaki rzadkie, potrawy-dzieła sztuki. Wspomina się to potem przez całe życie. Istnieje też we Francji turystyka "gastronomiczna”, w sensie poznawania obcych kultur poprzez kuchnię. Jakby charakter narodowy wyrazal się przez podniebienie, a fizyczny kontakt przez zołądek był jakimś ekwiwalentem biblijnego ,.poznawania” cielesnego drugiej osoby; tu: innego kraju. Świadczy to tylko o monotonii życia we współczesnym społeczeństwie, gdzie posiłki stają się wydarzeniami - nie do porównania z przyspieszeniami historii ostatnich kilkudziesięciu lat w Polsce.

W sumie obecne różnice zachowań przy stole między obu kulturami dają się sprowadzić do dwóch sposobów picia: „do dna” polskiego i francuskiego sączenia po kropelce. W Polsce mniej ważny będzie smak, bardziej efekt w żolądku, ciepło wewnętrzne, świąteczna, odrębna przestrzeń jakiegoś lepszego, biesiadnego świata. Wreszcie komunia duchowa wspólbiesiadników. We Francji - smakowanie chwili, indywidualne przeżycie, ciekawe, wzbogacające spotkania.

Te różnice związane z rytuałami jedzenia i picia wydają mi się ważniejsze niż klasyczne oc czasów Lévy-Straussa przeciwstawienie kuchni surowego, pieczonego i duszonego. $Z$ pew. nością w kuchni francuskiej dominuje pieczyste (czasem na pół surowe), choć oczywiści 
przy bogactwie rozmaitych dań regionalnych występują liczne potrawy duszone (jak w kuchni prowansalskiej). W Polsce zdecydowanie przewazaja potrawy duszone - nawet befsztyki wołowe podaje się tu przyrządzone jak zrazy - w sosie cebulowym. Widać tı wyraźne wpływy niemieckie, wyrażające siç również w stownictwie kuchennym (poczynając od samego slowa „kuchnia”, od die Kïche).

Rytualy towarzyskie wydają mi się jednak ważniejsze i trudniej postrzegalne, bo w każdej kulturze norma uchodzi za „normahność”. Wiadomo, normy ewoluują, i wraz z turystyką i globalizacją następuje coraz szersza wymiana wzorów. W obu krajach. Nie wydaje się ona na razie dotykać rdzenia przyzwyczajeń kulturowych. Ale trzeba będzie o przemianach też parę słów powiedzieć.

\section{Na zakończenie - perspektywa przemian}

Zanim przejdziemy do tendencji ewolucyjnych we współczesnym spoleczeństwic konsumpcyjnym, postarajmy się schematycznie określić różnice między paradygnatami jedzenia i picia we Francji i w Polsce.

Otóż na ogół rytuały jedzenia, a zwłaszcza picia, kodyfikują najważniejsze postawy i typy relacji każdej kultury. I tak w odwohującej się do Oświecenia i klasyki kulturze Francji picie służy intensyfikacji indywidualnych przeżyć, ostrzejszemu postrzeganiu świata dnia i grom rozumu (jeux de l'esprit). W przepojonej romantyczuym duchem Polsce rytuały upijania się wódką służą dotarciu do świata nocy, zbiorowej nieświadomości: braterstwa, solidarności, kommii duchowej. Należy dodać, że są to z pewnością dane historycznie zmienne, gdyż rytuały picia szlachty sprzed rozbiorów miały jednak inny charakter, choćby ze względu na to, że szlachta pijała przeważnie wino - miód i węgrzyna. Wódka była napojem chlopskim. We Francji też obyczaje się zmieniają, na przyklad szampan i w ogóle wina wytrawne wprowadzono dopiero stosunkowo niedawno, w XIX wieku. Analiza sposobów jedzenia jest mnicj jednoznaczna niż picia, ale potwierdza ogólne tendencje kontrastowe między dwoma kulturami.

Nobilitacja piwa po 1989 roku w Polsce - ale też w pewnej mierze we Francji, gdzie zwhaszcza młodzież spędza wieczory, sącząc piwo, a stronią̧c od wina - wprowadza nowe wymiary kulturowe rytualu. Z piwem to zabawne - przez dziesięciolecia PRL-u władza komunistyczna usiłowała rozpowszechnić tanie piwo, by wykorzenić zwyczaj upijania się wódką nie tylko bez skutku, ale lekarstwo okazało się gorsze od choroby. Budki z piwem staly się przekleństwem pejzażu ówczesnych miast. Obecnie piwo jest drogie, ale za to stało się wytworne, zapewne pod wpływem wzorów niemieckich. Pije się je w wytwornych kawiarniach, przy poważnych spotkaniach... na ogól nie upijając się. Czyli kapitalizm się raz jeszcze okazal skuteczniejszy od socjalizmu; czy może raczej chodzi o tendencję cywilizacyjną i wzory rozpowszechniane przez media?

Świadczyłoby o tym równoległe rozprzestrzenienie się fast-foodóu', rozmaitych Mc Donaldów, które się stały światowym emblematem globalizacji. We Francji, w środowiskach pros- 
tszych nawet pójście z rodziną i dziećmi na niedzielny obiad do McDonalda zastępuje teraz często uroczyste posilki rodzinne. Młodzi ze wszystkich środowisk umawiają się tam na randkę, i wolą hamburgery oraz coca-colę czy piwo od wyrafinowanych win, potraw i nudnej dla nich konwersacji.

Te tendencje wydają się jednak naskórkowe, nie dotykają istoty zwyczajów kulturowych. Mlodzi idą we Francji do McDonalda, by tam pogadać, i choć nie jest to wyrafinowana jeux d'esprit, jest jej demokratycznym, egalitarnym odpowiednikiem. A w Polsce dyskusja przy piwie - choć głośniejsza na ogół niz we Francji — pozwala bez upijania się odnaleźć kulturowe przyzwyczajenie - kontakt szczerej rozmowy, wynurzeí.

Ilość konsumowanego alkoholu czy wina bardzo się we Francji zmniejszyła, a jak się wydaje, w Polsce niewiele, ale zakaz picia w micjscach publicznych spowodowat pojawienie się na ulicy pijaków z butelkanni owiniętymi w szarą torbę papierową, jak na amerykańskich filmach, albo wręcz trunck przelewany jest do jakiejś butelki po oranżadzie. We Francji natomiast kloszardzi nie kryją się ze swą nieodstępną butlą taniego czerwonego wina. To są różnice, by tak to określić, folkloru ulicznego. A jak jest ze środowiskami opiniotwórczymi?

Wyraźna jest tendencja wśród inteligencji - która już jednak nie ma chyba monopolu tworzenia normy - by urozmaicać dość nonotonną polską ciężką kuchnię surówkami à la française, a wino zastępuje coraz częściej wódkę. Mniej też dąży się do upijania się. Czy zmieniają się od tego maniery przy stole? Chyba nie tak bardzo, a w każdym razie chyba nie strukturalnie. Szkic obecny jest jednak ankietą - badaniem, które każdy zainteresowany powinien dalej prowadzić na wlasną rękę (nie nadwerężając wątroby!). Czego wszystkim życzy autor.

Roizon, 24. 07. 2004 